\title{
Distribution and Diversity of Rhizobial Populations Associated with Acacia senegal (L.) Willd. Provenances in Senegalese Arid and Semiarid Regions
}

\author{
Niokhor Bakhoum ${ }^{1,2^{*}}$, Christine Le Roux ${ }^{3}$, Diégane Diouf ${ }^{1,2}$, Aboubakry Kane ${ }^{1,2}$, \\ Fatou Ndoye ${ }^{1,2}$, Dioumacor Fall ${ }^{2,4}$, Robin Duponnois ${ }^{3}$, Kandioura Noba ${ }^{2}$, \\ Samba Ndao Sylla ${ }^{1,2}$, Antoine Galiana ${ }^{3}$ \\ ${ }^{1}$ Plant Biology Department, Cheikh Anta Diop University of Dakar (UCAD), Dakar, Senegal \\ ${ }^{2}$ Bel-Air Research Center IRD/ISRA/UCAD, Common Microbiology Laboratory (LCM), Dakar, Senegal \\ ${ }^{3}$ Baillarguet Research Center UMR 113 IRD/CIRAD UMR82/AGRO-M/UM2, USC INRA 1242, \\ Laboratory of Tropical and Mediterranean Symbioses (LSTM), Montpellier, France \\ ${ }^{4}$ National Centre of Forest Research (CNRF)/Senegalese Institute of Agricultural Research (ISRA), \\ Dakar, Senegal \\ Email: "niokhor.bakhoum@gmail.com
}

Received November $27^{\text {th }}, 2013$; revised December $31^{\text {st }}, 2013$; accepted January $16^{\text {th }}, 2014$

Copyright (C) 2014 Niokhor Bakhoum et al. This is an open access article distributed under the Creative Commons Attribution License, which permits unrestricted use, distribution, and reproduction in any medium, provided the original work is properly cited. In accordance of the Creative Commons Attribution License all Copyrights (C) 2014 are reserved for SCIRP and the owner of the intellectual property Niokhor Bakhoum et al. All Copyright (C) 2014 are guarded by law and by SCIRP as a guardian.

\begin{abstract}
Distribution and diversity of rhizobial strains associated with Acacia senegal (L.) Willd. in relation to seed provenances in soils from arid (Dahra) and semiarid (Goudiry) zones of Senegal were investigated. PCR-RFLP performed on 16S-23S rDNA intergenic spacer (IGS) of nodule crude extracts revealed a high genetic diversity of rhizobial strains, which was higher in the semiarid region than in the arid region. The distribution of rhizobial populations was influenced by soil physical and chemical characteristics, and by $A$. senegal provenances as shown by the analysis of correspondence. In contrast, the phenotypic diversity of rhizobial strains was not correlated with the soil origin. The phylogenetic tree (performed by the maximum likelihood algorithm) of IGS 16S-23S sequences showed that most of the rhizobial strains nodulating $A$. senegal were closely related to Mesorhizobium plurifarium. Our results showed that rhizobial taxa associated with $A$. senegal were mainly distributed according to soil physical and chemical characteristics, and $A$. senegal provenances. A large subset of $A$. senegal root-nodulating bacteria had high diversity that correlated with the most favourable environmental conditions. Understanding the diversity and distribution of rhizobial strains may be exploited in the formulation of $A$. senegal inoculants for different seed provenances for resilience to soil stresses in various environmental conditions.
\end{abstract}

Keywords: Acacia senegal; Mesorhizobium; Diversity; Symbiosis; Ecology; Phylogeny

\section{Introduction}

Many legume trees significantly contribute to the nitrogen balance of tropical wetlands and rainforests (Dommergues, 1995; Pons et al., 2007; Roggy et al., 1999), and thus play an important role in their function and ecology. The prevalence of legumes to inhabit different environmental conditions might be related to their ability to associate with rhizobia, which enable them to fix atmospheric nitrogen (Moreira et al., 1992). Among these legumes, $A$. senegal is a species of major importance for the reforestation of arid and semiarid zones in sub-Saharian Africa. This multipurpose species is much valued by rural populations as a source of fodder and timber, and gum arabic (Muller \& Okoro, 2004). Thus, research on phenotypic and genotypic diversity of microsymbionts, their nodulation and symbiotic performances, becomes necessary. Diversity is of major

${ }^{*}$ Corresponding author. importance in the function of root nodulating communities by imparting greater resilience to soil stresses (Bala \& Giller, 2007). Keyser et al. (1993) reported that the efficient exploitation of biological nitrogen fixation to improve agricultural productivity required the characterization and isolation of a population of native rhizobia.

Rhizobia are a taxonomically diverse and phylogenetically heterogeneous group divided into alpha, and beta-proteobacteria. Recently, numerical genotypic analyses revealed large genetic diversity among root-nodulating bacteria able to nodulate A. senegal (de Lajudie et al., 1998; Fall et al., 2008; Sarr et al., 2005a). However, these studies did not take into account various environmental conditions. Thus, information about the relationships between the diversity of rhizobial strains associated with $A$. senegal and environmental conditions remains sparse. Before inoculation, knowledge of these relationships is crucial for formulation of appropriate A. senegal inoculants for 
different seed provenances for resilience to soil stresses in various environmental conditions. Indeed, several authors showed that environmental stresses, such as soil acidity or salinity, were detrimental to the survival and diversity of natural rhizobial populations and to their ability to establish symbiotic associations (Bala et al., 2003; Diouf et al., 2007).

Rhizobial populations diversity could be greatly influenced by the plant provenance used for trapping. Liu et al. (2005) suggested to analyze rhizobia from different geographic regions together with their host plants in order to characterize better interactions between rhizobia, legumes and geographical factors. Previous studies showed diversity in A. senegal provenances in Senegal (Chevallier et al., 1994). The differences between provenances could thus be reflected in their associations with rhizobial strains.

Our study aimed to determine the distribution, and to compare the diversity of rhizobial strains associated with $A$. senegal in two pedoclimatic zones (arid and semiarid regions) of Senegal. It was essential to highlight the relationships between rhizobia, soil conditions and $A$. senegal provenances. Thus, the diversity of rhizobia occurring under $A$. senegal in natural stands was assessed and compared with both those developing in an $A$. senegal plantation and in bulk soil, in relation with $A$. senegal provenances.

\section{Materials and Methods}

\section{Host Plant and Soil Samplings}

Three Senegalese A. senegal provenances, collected in February 2008, from Dahra (sylvopastoral zone, Lat. $15^{\circ} 21^{\prime} \mathrm{N}$; Long. $15^{\circ} 29^{\prime} \mathrm{W}$ ), Ngane (groundnut basin, Lat. $14^{\circ} 13^{\prime} \mathrm{N}$; Long. $16^{\circ} 12^{\prime} \mathrm{W}$ ) and Kidira (east of Senegal, Lat. $14^{\circ} 24^{\prime} \mathrm{N}$; Long. $12^{\circ} 15^{\prime} \mathrm{W}$ ) natural stands were tested for nodulation. Soil samples were collected in Dahra and Goudiry, in Senegal, and analyzed as described by Bakhoum et al. (2012). In each zone, soil under four $A$. senegal trees separated by a distance of at least 10 to 15 $\mathrm{m}$ were randomly selected, in plantation and in natural stand, and sampled around the trunk (East, West, North and South) and pooled. Four soil cores were also randomly sampled in bulk soil and pooled in the same conditions.

\section{Rhizobial Trapping}

Seeds of the three $A$. senegal provenances were used in the trapping tests. Seed germination was conducted as described by Sarr et al. (2005b). Rhizobial isolates were trapped in vitro on roots of A. senegal seedlings grown in Gibson tubes (Gibson, 1963). After 1 week of growth, $1 \mathrm{ml}$ of soil suspension was added to each tube. Soil suspension was obtained with $10 \mathrm{~g}$ of each composite soil sample, stirred for $1 \mathrm{~h}$ in $90 \mathrm{ml}$ of sterile buffered saline, pH 7 ( NaCl, $0.15 \mathrm{~mol} \cdot \mathrm{l}^{-1} ; \mathrm{KH}_{2} \mathrm{PO}_{4}, 0.002$ $\left.\mathrm{mol} \cdot \mathrm{l}^{-1} ; \mathrm{Na}_{2} \mathrm{HPO}_{4}, 0.004 \mathrm{~mol} \cdot \mathrm{l}^{-1}\right)$. Four replicates were tested for each soil. Uninoculated plants were used as controls.

\section{Rhizobial Isolation and PCR-RFLP of 16S-23S rDNA Intergenic Spacer (IGS)}

Nodules collected in situ (from Goudiry A. senegal plantation in August 2008) and in vitro were surface sterilized, isolated, and authenticated cultures preserved as described by Fall et al. (2008). Polymerase chain reactions (PCR) were carried out, on the IGS rDNA of 42 isolates, directly on $2 \mu \mathrm{l}$ of fresh bacterial culture suspended in $50 \mu \mathrm{l}$ sterile water, and digested as described by Fall et al. (2008). Shannon diversity index was calculated according to Borcard \& Buttler (2001). The relationship between $A$. senegal provenances and IGS-RFLP profiles was studied by the analysis of correspondence. Thus, in addition to $A$. senegal provenances used for trapping bacteria, Goudiry plantation (Goudiry provenance), where in situ nodules were collected, was considered as a provenance.

\section{Infectivity and Effectiveness Tests}

Infectivity and effectiveness tests were carried out with Dahra provenance because of its higher nodulation rate with the soil samples after trapping. Germination, inoculation and plant cultivation were conducted as described by Diouf et al. (2007). Infectivity and effectivity of rhizobial isolates were evaluated by counting the number of nodules and from the dry weight of the produced nodules and shoots in relation to control, respectively. Each IGS-RFLP profile was represented by its most efficient rhizobial isolate. Selected rhizobial strains were used for phylogenetic and phenotypic characterization.

\section{Phylogeny of IGS 16S-23S rRNA}

The partial sequence of the IGS region of 14 rhizobial strains was investigated. PCR were performed with $2 \mu \mathrm{l}$ of bacterial culture, as described above, in $25 \mu \mathrm{l}$ reaction tube containing $0.625 \mathrm{U}$ of Taq polymerase according to Diouf et al. (2007). The partial IGS region was amplified using primers $\mathrm{Br} 5$; 5'-CTT-GTA-GCT-CAG-TTG-GTT-AG-3' (Willems et al., 2001) and 23S-38; 5'-CCG-GGT-TTC-CCC-ATT-CGG-3' (Normand et al., 1992).

PCR products were checked according to Diouf et al. (2007). Expected bands were excised and DNA was purified using PureLink $^{\mathrm{TM}}$ Gel Extraction Kit (Invitrogen, USA) according to the manufacturer's instructions. The IGS rRNA was sequenced (Genoscreen, France) with the same primers used for PCR. Amplified sequences were assembled with ChromasPro Program (Technelysium Pty. Ltd., Australia). Closely related sequences held in GenBank were retrieved with Blast algorithm and included in the phylogenetic analysis. Multiple alignments were performed with ClustalX and Genedoc software packages. Phylogenetic and molecular evolutionary analyses were conducted using MEGA version 5 (Tamura et al., 2011) with the maximum likelihood algorithm, and the stability of groupings was assessed by performing a bootstrap analysis. Azorhizobium caulinodans strain ORS $571^{\mathrm{T}}$ was used as outgroup reference. The obtained sequences were deposited in GenBank database under accession numbers: JQ606813 to JQ606826.

\section{Phenotypic Characteristics of Rhizobial Strains}

The 14 rhizobial strains were compared by performing a numerical analysis of 52 phenotypic features. For each test, a control was performed, and inoculation and incubation were performed as described by Diouf et al. (2010). The use of various carbohydrates (filter-sterilized, $0.2 \mu \mathrm{m}$ ) by rhizobial was tested on MGS agar plates (Diouf et al., 2008) according to the method described by Mohamed et al. (2000). The intrinsic resistance of rhizobial to heavy metals was determined on tryptone-yeast extract (TY) agar plates (Zhang et al., 1991) containing heavy metals. The intrinsic antibiotic resistance of rhizobial strains was tested on YMA (yeast extract mannitol) agar plates containing 
filter-sterilized $(0.2 \mu \mathrm{m})$ antibiotics.

\section{Statistical Analysis}

Data from the infectivity and effectiveness tests were analyzed with SPSS software version 13 according to StudentNewman-Keuls $(P<0.05)$. An analysis of correspondence was carried out to determine the distribution of IGS-RFLP profiles in relation to plant provenances. Figures were obtained with XLSTAT software version 2010. A dendrogram performed with Ward method and Euclidian distance on the numerical analysis of phenotypic traits was built with $\mathrm{R}$ software (version $\mathrm{R}-2.13 .0)$.

\section{Results and Discussion}

\section{Soil Properties and Nodulation}

The soil samples from arid (Dahra) and semiarid (Goudiry) regions of Senegal were sandy with a higher percentage of clay and silt in those from the semiarid region (Table 1). Soil $\mathrm{pH}$ was slightly acidic in both sites and did not vary significantly, regardless of the vegetation cover. Total C, total N, Ca, Mg and $\mathrm{K}$ contents were higher in Goudiry soil than in Dahra soil. Significant differences $(P<0.05)$ in total $\mathrm{C}$, total $\mathrm{N}$ and $\mathrm{K}$ were found between $A$. senegal plantation soils in Dahra and Goudiry. By contrast, Dahra soil showed higher values of available P. In the present study, we observed a higher $A$. senegal nodulation rate in Goudiry soils (Table 2). This suggests that the result of the in vitro nodulation test depends on the survival of rhizobia that are associated with soil aggregates (Mendes \& Bottomley, 1998; Postma et al., 1990). Bulk soil samples of both regions did not promote nodule formation. Authors describe that legumes can be responsible for shifts in the soil bacterial community composition (Bakhoum et al., 2012; Lorenzo et al., 2010), including changes in the communities of symbiotic nitrogen- fixers (Rodríguez-Echeverría, 2010).

\section{Distribution of Rhizobial Strains in the Two Regions}

Results showed a large diversity of rhizobial strains from Senegalese arid and semiarid zones associated with $A$. senegal based on IGS 16S-23S rDNA (Table 2). They agree with previous studies which highlight considerable genetic diversity in the microsymbionts originating from the Sahel (Diouf et al., 2007; Fall et al., 2008; Sarr et al., 2005a). The 42 isolates were shared out into 14 IGS-RFLP profiles: three exclusively found in Dahra, nine specific to Goudiry and two that occurred in both regions. Data evidenced a distribution of rhizobial strains according to the geographic location in Senegal. Similar results were found by Amrani et al. (2010) on Acacia saligna plants in Algerian soils which were nodulated by different rhizobial populations according to their geographical origin (i.e. Northern vs Southern areas). Results of Shannon diversity index $\left(H^{\prime}\right)$ showed that the genetic diversity of rhizobial strains was higher in Goudiry semiarid region than in Dahra arid region. However, Diouf et al. (2007) and Sylla et al. (2002) did not find any clear relationship between rhizobial strain diversity and ecogeographical origin.

\section{Infectivity and Effectiveness of Isolates}

The 42 rhizobial isolates were all able to re-nodulate $A$. senegal seedlings in vitro. Results showed that among the strains selected as representative of IGS-RFLP profiles (Table 2), ORS 3604 significantly $(P<0.05)$ increased the nodule number compared to ORS 3628 and ORS 3588. However the strains ORS 3573, ORS 3574, ORS 3576, ORS 3593, ORS 3604, ORS 3588, ORS 3600, ORS 3598, ORS 3610 and ORS 3607 significantly $(P<0.05)$ improved the shoot dry matter compared to non-inoculated control. The nodule dry matter was not signifi-

Table 1.

Soil properties of Dahra (arid) and Goudiry (semiarid) sites.

\begin{tabular}{|c|c|c|c|c|c|c|}
\hline \multirow{2}{*}{ Soil components ${ }^{*}$} & \multicolumn{3}{|c|}{ Dahra soil } & \multicolumn{3}{|c|}{ Goudiry soil } \\
\hline & Bulk soil & Plantation & Natural stand & Bulk soil & Plantation & Natural stand \\
\hline \% Clay & $2.60 \pm 0.10^{\mathrm{d}}$ & $3.57 \pm 0.87^{\mathrm{c}}$ & $5.53 \pm 0.15^{b}$ & $6.76 \pm 0.23^{\mathrm{a}}$ & $6.87 \pm 0.46^{\mathrm{a}}$ & $6.47 \pm 0.05^{\mathrm{a}}$ \\
\hline$\%$ Silt & $10.26 \pm 0.04^{\mathrm{c}}$ & $10.30 \pm 1.97^{\mathrm{c}}$ & $11.01 \pm 0.18^{\mathrm{C}}$ & $15.20 \pm 0.55^{\mathrm{b}}$ & $19.10 \pm 2.62^{\mathrm{a}}$ & $18.23 \pm 0.40^{\mathrm{a}}$ \\
\hline$\%$ Sand & $86.98 \pm 0.44^{\mathrm{a}}$ & $85.30 \pm 1.73^{\mathrm{ab}}$ & $83.09 \pm 0.22^{b}$ & $79.32 \pm 0.32^{\mathrm{c}}$ & $73.87 \pm 2.69^{d}$ & $75.46 \pm 0.68^{\mathrm{d}}$ \\
\hline \% Total C & $0.41 \pm 0.01^{\mathrm{d}}$ & $0.52 \pm 0.10^{\mathrm{c}}$ & $0.82 \pm 0.01^{b}$ & $0.74 \pm 0.04^{b}$ & $0.77 \pm 0.07^{\mathrm{b}}$ & $1.71 \pm 0.02^{\mathrm{a}}$ \\
\hline$\%$ Total N & $0.04 \pm 0.01^{\mathrm{d}}$ & $0.05 \pm 0.01^{\mathrm{d}}$ & $0.08 \pm 0.01^{\mathrm{b}}$ & $0.06 \pm 0.01^{\mathrm{c}}$ & $0.07 \pm 0.01^{\mathrm{b}}$ & $0.16 \pm 0.01^{\mathrm{a}}$ \\
\hline Available P $\left(\mathrm{mg} \cdot \mathrm{kg}^{-1}\right)$ & $12.66 \pm 0.20^{\mathrm{b}}$ & $8.01 \pm 1.82^{\mathrm{C}}$ & $29.66 \pm 0.25^{\mathrm{a}}$ & $7.47 \pm 0.11^{\mathrm{c}}$ & $8.29 \pm 0.01^{\mathrm{c}}$ & $9.16 \pm 0.06^{\mathrm{C}}$ \\
\hline Total P $\left(\mathrm{mg} \cdot \mathrm{kg}^{-1}\right)$ & $33.11 \pm 0.12^{d}$ & $49.00 \pm 13.08^{c}$ & $83.03 \pm 0.10^{b}$ & $53.00 \pm 2^{c}$ & $79.33 \pm 8.14^{b}$ & $166.00 \pm 3.0^{\mathrm{a}}$ \\
\hline \% Mg (meq) & $0.53 \pm 0.02^{b}$ & $0.42 \pm 0.06^{\mathrm{b}}$ & $0.56 \pm 0.05^{b}$ & $0.29 \pm 0.08^{b}$ & $0.42 \pm 0.12^{\mathrm{b}}$ & $3.57 \pm 0.40^{\mathrm{a}}$ \\
\hline \% K (meq) & $0.19 \pm 0.01^{\mathrm{c}}$ & $0.20 \pm 0.02^{c}$ & $0.29 \pm 0.01^{b}$ & $0.27 \pm 0.02^{b}$ & $0.28 \pm 0.03^{\mathrm{b}}$ & $0.90 \pm 0.07^{\mathrm{a}}$ \\
\hline \% Na (meq) & $0.09 \pm 0.01^{\mathrm{ab}}$ & $0.11 \pm 0.09^{\mathrm{ab}}$ & $0.15 \pm 0.01^{\mathrm{a}}$ & $0.14 \pm 0.03^{\mathrm{a}}$ & $0.15 \pm 0.04^{\mathrm{a}}$ & $0.03 \pm 0.01^{\mathrm{b}}$ \\
\hline
\end{tabular}

${ }^{*}$ The 0 to 25-cm-deep analysed soil samples were collected in areas not covered by A. senegal trees (bulk soil), and under A. senegal trees in plantation and in natural stands at Dahra and Goudiry. For each parameter analysed, means of values followed by the same letter on each line are not significantly different according to NewmanKeuls test at $5 \%$. 
Table 2.

Shannon diversity index, distribution and effectiveness of rhizobial IGS-RFLP profiles. The most efficient isolates (in bold) were selected as representative of each IGS-RFLP profile and their values were showed. ${ }^{*}$ mean nodule number per plant; ${ }^{* * *}$ nodule dry matter; ${ }^{* * *}$ shoot dry matter. In each column, means values followed by the same letter were not significantly different according to Newman-Keuls test at $5 \%$.

\begin{tabular}{|c|c|c|c|c|c|c|c|c|}
\hline \multirow[b]{2}{*}{ Site } & \multirow[b]{2}{*}{$\begin{array}{l}\text { Shannon } \\
\text { index }\end{array}$} & \multirow[b]{2}{*}{ Soil origin } & \multirow[b]{2}{*}{ Rhizobial isolate } & \multirow[b]{2}{*}{$\begin{array}{l}\text { IGS-RFLP } \\
\text { profile }\end{array}$} & & \multicolumn{3}{|c|}{ Infectivity and effectiveness test } \\
\hline & & & & & & Nod no ${ }^{*}$ & $\begin{array}{c}\text { NDM }^{* *} \\
\left(\text { mg·plant }^{-1}\right)\end{array}$ & $\begin{array}{c}\text { SDM }^{* * *} \\
\left(\text { mg•plant }^{-1}\right)\end{array}$ \\
\hline \multirow[t]{5}{*}{ Dahra } & 0.638 & $\begin{array}{c}\text { Dahra } \\
\text { plantation }\end{array}$ & $\begin{array}{c}\text { ORS 3575, ORS 3580, ORS } \\
3581\end{array}$ & I & & & & \\
\hline & & & ORS 3572, ORS 3573 & II & & $11.5^{\mathrm{abcd}}$ & $5.37^{\mathrm{a}}$ & $124.8^{\mathrm{a}}$ \\
\hline & & & ORS 3574 & III & & $16^{\mathrm{ab}}$ & $6.55^{\mathrm{a}}$ & $127.2^{\mathrm{a}}$ \\
\hline & & & ORS 3576, ORS 3577 & IV & & $12.2^{\mathrm{abcd}}$ & $3.8^{\mathrm{a}}$ & $120.5^{\mathrm{a}}$ \\
\hline & & & ORS 3578, ORS 3579 & $\mathrm{~V}$ & & $12.7^{\text {abcd }}$ & $2.9^{\mathrm{a}}$ & $112^{\mathrm{ab}}$ \\
\hline \multirow[t]{9}{*}{ Goudiry } & 0.933 & $\begin{array}{l}\text { Goudiry } \\
\text { plantation }\end{array}$ & $\begin{array}{l}\text { ORS 3585, ORS 3605, ORS } \\
\text { 3628, ORS 3630, ORS 3631, } \\
\text { ORS 3632, ORS } 3633\end{array}$ & $\mathrm{I}$ & & $9.2^{\text {bcd }}$ & $4.3^{\mathrm{a}}$ & $99.2^{\mathrm{ab}}$ \\
\hline & & & $\begin{array}{l}\text { ORS 3589, ORS 3593, ORS } \\
\text { 3590, ORS 3599, ORS } 3594\end{array}$ & VI & & $16^{\mathrm{ab}}$ & $5.3^{\mathrm{a}}$ & $118.5^{\mathrm{a}}$ \\
\hline & & & ORS 3591, ORS 3604 & VII & & $28^{\mathrm{a}}$ & $6.2^{\mathrm{a}}$ & $145^{\mathrm{a}}$ \\
\hline & & & $\begin{array}{c}\text { ORS 3584, ORS 3602, ORS } \\
\text { 3588, ORS } 3601\end{array}$ & VIII & & $9^{\text {bcd }}$ & $5.4^{\mathrm{a}}$ & $130.7^{\mathrm{a}}$ \\
\hline & & & ORS 3595, ORS 3600 & IX & & $15.7^{\mathrm{ab}}$ & $5.4^{\mathrm{a}}$ & $133.5^{\mathrm{a}}$ \\
\hline & & & ORS 3596, ORS 3597 & $\mathrm{X}$ & & $12.7^{\mathrm{abcd}}$ & $3^{\mathrm{a}}$ & $96.7^{\mathrm{ab}}$ \\
\hline & & & ORS 3598 & XI & & $13.2^{\mathrm{abcd}}$ & $2.8^{\mathrm{a}}$ & $123.5^{\mathrm{a}}$ \\
\hline & & & ORS 3603 & XIII & & $11.2^{\mathrm{abcd}}$ & $2.1^{\mathrm{a}}$ & $98.2^{\mathrm{ab}}$ \\
\hline & & $\begin{array}{l}\text { Goudiry } \\
\text { natural stand }\end{array}$ & $\begin{array}{l}\text { ORS 3606, ORS 3610, ORS } \\
\text { 3608, ORS 3609, ORS 3611, } \\
\text { ORS } 3612\end{array}$ & XII & & $12^{\mathrm{abcd}}$ & $5.2^{\mathrm{a}}$ & $115.5^{\mathrm{a}}$ \\
\hline
\end{tabular}

cantly different between inoculated treatments.

\section{Relationship between Rhizobium Diversity and A. senegal Provenances}

Results of analysis of correspondence showed that the first two axes explained $80.83 \%$ of total data variability which expressed high affinity between some IGS-RFLP groups and $A$. senegal provenances (Figure 1). Three clearly distinct groups were thus identified: the close association of Kidira provenance with IGS-RFLP profiles V and VII; that of Goudiry provenance with profiles I and III; and that of Dahra provenance with profiles II, IV, VI, VIII, IX, XI, XIII, and to a lesser extent XIV. It suggests that $A$. senegal trees may select their symbiotic partners. Consequently, their genetic polymorphism is reflected in their nodulation as suggested by Sarr et al. (2005b).

\section{Phylogeny of IGS 16S-23S rRNA}

Rhizobial strains were clustered with Mesorhizobium plurifarium from their partial IGS rRNA sequences (Figure 2). Four clusters were distinguished. Cluster I comprised six strains that showed about 99\% similarity with strains ORS 3365 and ORS 3356 isolated from A. seyal in the Senegalese groundnut basin. Strains of cluster II were closely related to the type strain of $M$. plurifarium LMG $11892^{\mathrm{T}}$ with $99 \%$ similarity. Cluster III was made of one strain which had 99\% similarity with ORS 3404 isolated from A. seyal in the Senegalese groundnut basin, and 98\% similarity with strains CIRADF 165 and ORS 3359 isolated from Acacia nilotica in Mauritania and from A. seyal in the Senegalese groundnut basin, respectively. Cluster IV contained four strains, which were close to M. plurifarium strains isolated from Acacia mangium in Senegal, i.e. CIRADAc8 and CIRADAc15, and to strain CCBAU 45272 associated with Astragalus in China. M. plurifarium strains were already isolated from nodules of Acacia, Leucaena, Prosopis and Chamaecrista from West Africa (Senegal), East Africa (Sudan) and South America (Brazil) (de Lajudie et al., 1998), as well as from South America (Velazquez et al., 2001). Interestingly, our study revealed that IGS sequences exhibited clear diversity within M. plurifarium strains. Nevertheless, studies performed on A. senegal microsymbionts in Senegal showed that the species was nodulated by both the genera Mesorhizobium and Ensifer (de Lajudie et al., 1998) as well Rhizobium (Fall et al., 2008). Nick et al. (1999) reported that $A$. senegal was naturally and exclusively nodulated by Ensifer in Sudan. Moreover Njiti \& Galiana (1996) observed that A. senegal can form nodules with both Rhizobium and Bradyrhizobium strains under in vitro conditions but appeared to be only nodulated by Rhizobium strains in natural conditions. On the basis of studies performed in Senegal, $A$. senegal seems to be nodulated by $M$. plurifarium 


\section{N. BAKHOUM ET AL.}

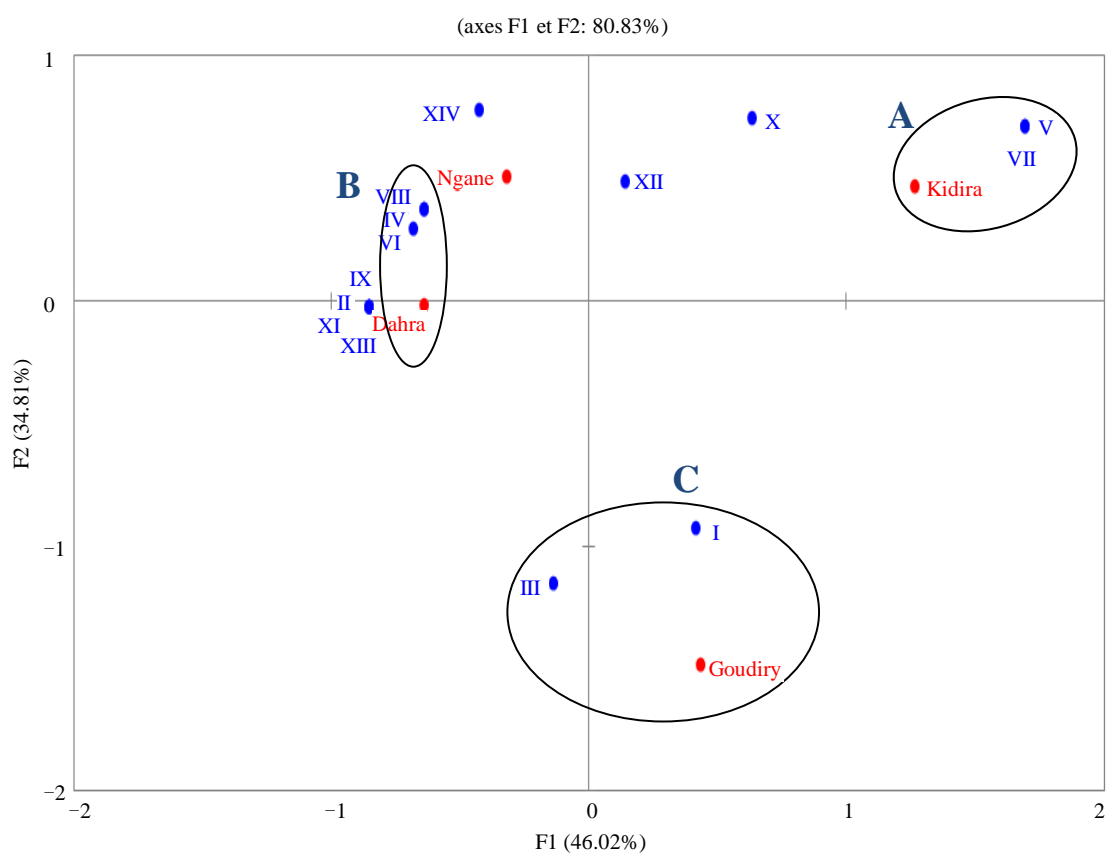

Figure 1.

Projection of 14 representative IGS-RFLP profiles of rhizobial isolates of soils originating from arid (Dahra) and semiarid (Goudiry) Senegalese zones, and Dahra, Ngane, Kidira, Goudiry A. senegal provenances on the first two axes determined by the factorial analysis of correspondence.

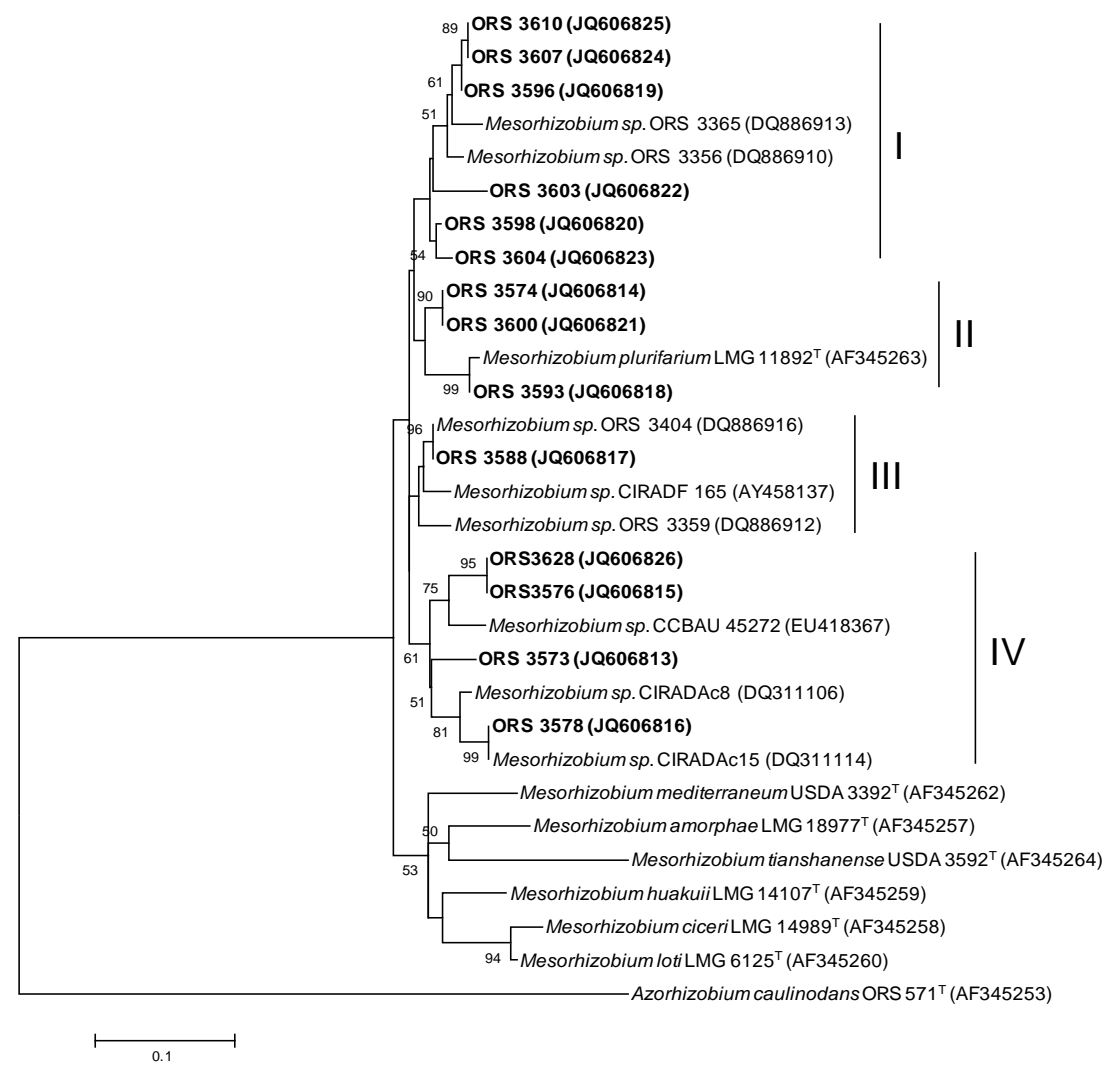

Figure 2.

Phylogenetic (maximum likelihood) tree based on aligned sequences of 16S-23S rDNA intergenic spacer (700 nt) using MEGA5. The accession numbers for the sequences are indicated in parentheses. The sequences generated in this work are shown in bold. Only bootstrap probability values $>50 \%$ (100 replicates) are indicated at the branching points. Type strains are indicated as (T). 
rather than Ensifer (Sinorhizobium) and Rhizobium. Ba et al. (2002) showed that Nod factors of rhizobia isolated from Acacia tortilis subsp. raddiana in Africa are identical or very close to Nod factors produced by other fast-growing Acacia nodulating rhizobia i.e. Sinorhizobium terangae ORS1073 and $M$. plurifarium ORS1001 isolated from A. senegal (Lorquin et al., 1997), strain GRH2 isolated from Acacia cyanophylla (LopezLara et al., 1995) and Rhizobium tropici CFN299 and CIAT899 (Folch-Mallol et al., 1996) isolated from bean. Since, as A. senegal appears to have strict requirements in regard to Nod factors the rhizobia that nodulate it produce (Ba et al., 2002), the species seems to be mainly nodulated by a type of rhizobia according to the geographic position.

\section{Phenotypic Properties of Rhizobial Isolates}

Rhizobial strains from both regions were phenotypically heterogeneous and formed four distinct clusters (Figure 3). The strains tested were linked with a similarity level of about $80 \%$. Majority of strains were able to metabolize all sugars except salicin. In addition, most of the strains tolerated heavy metals at the concentrations tested. However, all strains occurring in clusters A, B and C were sensitive to $\mathrm{CuSO}_{4}, \mathrm{HgCl}_{2}$ and $\mathrm{CdSO}_{4}$, Pb-acetate (1000) and $\mathrm{FeCl}_{3} \cdot 6 \mathrm{H}_{2} \mathrm{O}$ (750). Concerning antibiotics sensitivity, rhizobial strains were more sensitive to tetracycline. The strains isolated from $A$. senegal in our study exhibited a high phenotypic diversity. These results are consistent with those of Fall et al. (2008). In contrast to genotypic results based on IGS-RFLP profiles, the phenotypic diversity of rhizobial strains was not correlated to the geographical origin. However, Xavier et al. (1998) observed that the antibiotic sensitivity of rhizobial strains was influenced by climatic and soil conditions, respectively. These results may indicate that there is no relationship between the genotypic and phenotypic diversity of rhizobial strains. Similar results were reported by Elboutahiri et al. (2010) for Sinorhizobium strains nodulating Medicago sati$v a$ in Morocco. Contrary to our results, Fall et al. (2008) found a correlation between phenotypic and genotypic characteristics of $A$. senegal rhizobial strains from Senegalese dry land areas.

\section{Conclusion}

In conclusion, the distribution of root-nodulating bacteria associated with $A$. senegal was correlated to physical and chemical characteristics of the soils. The root-nodulating bacteria associated to $A$. senegal seemed to be selected by the seed provenance. Genotypic and phenotypic diversity of rhizobia associated with $A$. senegal is considerable in the Sahalian part of Senegal with an even higher genetic diversity in less drastic environmental conditions. A. senegal appears to be mainly nodulated by members of $M$. plurifarium strains in Senegal. In the future, specific studies on the symbiotic performances of rhizobial strains in relation to plant provenance and soil type should be performed aiming at selecting both symbionts in relation to environmental conditions.

\section{Acknowledgments}

This work was financially supported by ACACIAGUM INCO STREP project (No. 032233). We thank the Service de Coopération d'Action Culturelle of the France Embassy in Senegal for supporting our training courses in France, and Ir

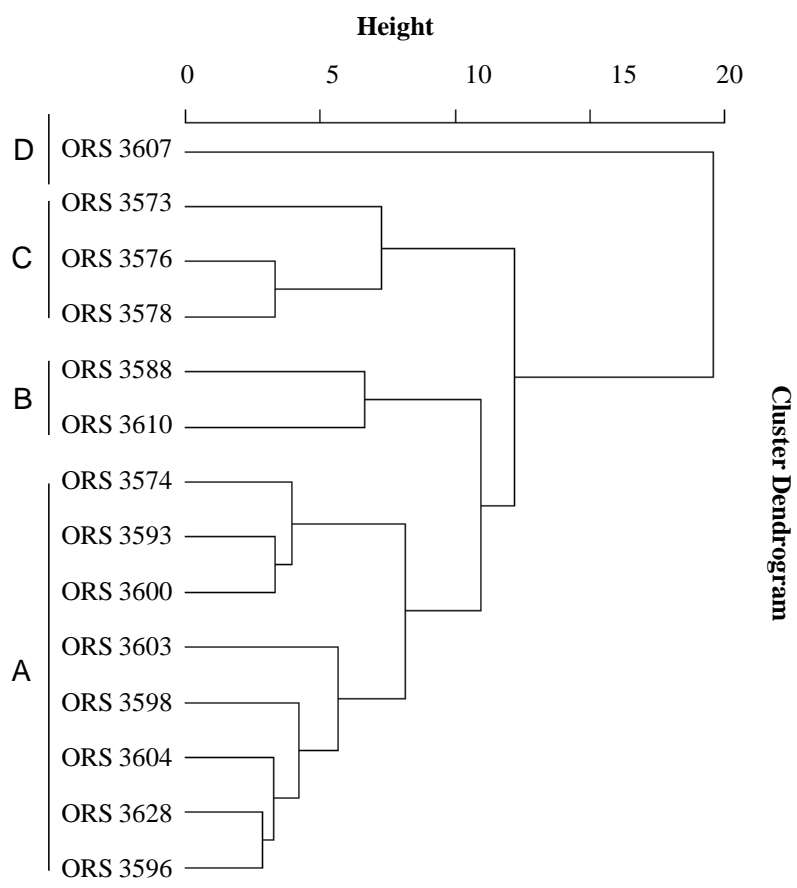

Figure 3.

Dendrogram showing phenotypic relationships between rhizobial strains representative of the 14 IGS-RFLP groups isolated from $A$. senegal based on similarity. Dendrogram was obtained from 52 phenotypic traits: 17 carbohydrate sources (ribose, D xylose, L (+)-rhamnose, L (+)-arabinose, D (+)-glucose, D (+)-galactose, saccharose, D $(+)$-maltose, trehalose, lactose, D (+)-raffinose, mannitol, glycerol, sorbitol, amidon, salicilin and levulose (Diouf et al., 2008)), 11 heavy metals $\left(\mu \mathrm{g} \cdot \mathrm{ml}^{-1}\right.$ ): $\mathrm{CuSO}_{4}, 5 \mathrm{H}_{2} \mathrm{O}(500) ; \mathrm{HgCl}_{2}$ (5); $\mathrm{CdSO}_{4}$ (50); $\mathrm{ZnSO}_{4}$ (250); $\mathrm{Pb}$-acetate (1000); $\mathrm{FeCl}_{3}, 6 \mathrm{H}_{2} \mathrm{O}$ (750); $\mathrm{MnCl}_{2}, 4 \mathrm{H}_{2} \mathrm{O}$ (1000); $\mathrm{MnSO}_{4}$ (1000); $\mathrm{MgSO}_{4}$ (1000); $\mathrm{BaCl}_{2}, 2 \mathrm{H}_{2} \mathrm{O}$ (1000) and $\mathrm{CoSO}_{4}(150)$ ) and 6 antibiotics: (kanamicin, streptomycin, ampicillin, chloramphenicol, tetracycline, rifampicin with four concentrations for each 10, 20, 50, $100 \mu \mathrm{g} \cdot \mathrm{ml}^{-1}$ ).

Oumar SADIO for R statistical analysis. The authors are grateful to Marie-Cécile Maraval (Cirad/TAC-112/A, Baillarguet, Montpellier) for the English editing.

\section{REFERENCES}

Amrani, S., Noureddine, N. E., Bhatnagar, T., Argandona, M., Nieto, J. J., \& Vargas, C. (2010). Phenotypic and genotypic characterization of rhizobia associated with Acacia saligna (Labill.) Wendl. in nurseries from Algeria. Systematic and Applied Microbiology, 33, 44-51. http://dx.doi.org/10.1016/j.syapm.2009.09.003

Ba, S., Willems, A., de Lajudie, P., Roche, P., Jeder, H., Quatrini, P. et al. (2002). Symbiotic and taxonomic diversity of rhizobia isolated from Acacia tortilis subsp. raddiana in Africa. Systematic and Applied Microbiology, 25, 130-145.

http://dx.doi.org/10.1078/0723-2020-00091

Bakhoum, N., Ndoye, F., Kane, A., Assigbetse, K., Fall, D., Sylla, S. N. et al. (2012). Impact of rhizobial inoculation on Acacia senegal (L.) Willd. growth in greenhouse and soil functioning in relation to seed provenance and soil origin. World Journal of Microbiology and Biotechnology, 28, 2567-2579. http://dx.doi.org/10.1007/s11274-012-1066-6

Bala, A., \& Giller, K. E. (2007). Relationships between rhizobial diversity and host legume nodulation and nitrogen fixation in tropical ecosystems. Nutrient Cycling in Agroecosystems, 76, 2-3. http://dx.doi.org/10.1007/s10705-005-2003-y 
Bala, A., Murphy, P. J., Osunde, A. O., \& Giller, K. E. (2003). Nodulation of tree legumes and the ecology of their native rhizobial populations in tropical soils. Applied Soil Ecology, 22, 211-223. http://dx.doi.org/10.1016/S0929-1393(02)00157-9

Borcard, D., \& Buttler, A. (2001). Ecologie numérique (p. 250). Montreal and Franche-Comte Universities, Montreal.

Chevallier, M. H., Brizard, J. P., Diallo, I., \& Leblanc, J. M. (1994). Genetic diversity in the Acacia senegal complex. Bois et Forêts des Tropiques, 240, 5-12.

de Lajudie, P., Willems, A., Nick, G., Moreira, F., Molouba, F., Hoste, B. et al. (1998). Characterization of tropical tree rhizobia and description of Mesorhizobium plurifarium sp. nov. International Journal of Systematic Bacteriology, 2, 369-382. http://dx.doi.org/10.1099/00207713-48-2-369

Diouf, D., Fall, D., Chaintreuil, C., Ba, A. T., Dreyfus, B., Neyra, M. et al. (2010). Phylogenetic analyses of symbiotic genes and characterization of functional traits of Mesorhizobium spp. strains associated with the promiscuous species Acacia seyal Del. Journal of Applied Microbiology, 108, 818-830. http://dx.doi.org/10.1111/j.1365-2672.2009.04500.x

Diouf, D., Forestier, S., Neyra, M., \& Lesueur, D. (2003). Optimisation of inoculation of Leucaena leucocephala and Acacia mangium with rhizobium under greenhouse conditions. Forest Science, 60, 379-384. http://dx.doi.org/10.1051/forest:2003029

Diouf, D., Ndoye, I., Fall, D., Kane, A., Ba, A. T., \& Neyra, M. (2008). Phenotypic and symbiotic characterization of Mesorhizobium spp. strains nodulating Acacia seyal Del. Journal of Science and Technology, 7, 1-10.

Diouf, D., Samba-Mbaye, R., Lesueur, D., Ba, A. T., Dreyfus, B., de Lajudie, P. et al. (2007). Genetic diversity of Acacia seyal Del. Rhizobial populations indigenous to Senegalese soils in relation to salinity and pH of the sampling sites. Microbial Ecology, 54, 553-566. http://dx.doi.org/10.1007/s00248-007-9243-0

Dommergues, Y. R. (1995). Nitrogen fixation by trees in relation to soil nitrogen economy. Fertilizer Research, 42, 215-230. http://dx.doi.org/10.1007/BF00750516

Elboutahiri, N., Thami-Alami, I., \& Udupa, S. M. (2010). Phenotypic and genetic diversity in Sinorhizobium meliloti and $S$. medicae from drought and salt affected regions of Morocco. BMC Microbiology, 10, 15. http://dx.doi.org/10.1186/1471-2180-10-15

Fall, D., Diouf, D., Ourarhi, M., Faye, A., Abdelmounen, H., Neyra, M. et al. (2008). Phenotypic and genotypic characteristics of Acacia senegal (L.) Willd. root-nodulating bacteria isolated from soils in the dryland part of Senegal. Letters in Applied Microbiology, 47, 85-97. http://dx.doi.org/10.1111/j.1472-765X.2008.02389.x

Folch-Mallol, J. L., Marroqui, S., Sousa, C., Manyani, H., Lopez-Lara, I. M., van der Drift, K. M. et al. (1996). Characterization of Rhizobium tropici CIAT899 nodulation factors: The role of nodH and nodPQ genes in their sulfation. Molecular Plant-Microbe Interactions, 9, 151-163. http://dx.doi.org/10.1094/MPMI-9-0151

Gibson, A. H. (1963). Physical environment and symbiotic nitrogen fixation. I. the effect of temperature on recently nodulated Trifolium subterraneum (L.) plants. Australian Journal of Biological Sciences, 16, 28-42.

Keyser, H. H., Somasegaran, P., \& Bohlool, B. B. (1993). Rhizobial ecology and technology. In F. Blaine Metting (Ed.), Soil microbial ecology: Applications in agricultural and environmental management (pp. 205-226). New York, NY: Marcel Dekker, Inc.

Liu, J., Wang, E. T., \& Chen, W. X. (2005). Diverse rhizobia associated with woody legumes Wisteria sinensis, Cercis racemosa and Amorpha fruticosa grown in the temperate zone of China. Systematic and Applied Microbiology, 28, 465-477. http://dx.doi.org/10.1016/j.syapm.2005.02.004

Lopez-Lara, I. M., van den Berg, J. D., Thomas-Oates, J. E., Glushka, J., Lugtenberg, B. J., \& Spaink, H. P. (1995). Structural identification of the lipo-chitin oligosaccharide nodulation signals of Rhizobium loti. Molecular Microbiology, 15, 627-638. http://dx.doi.org/10.1111/j.1365-2958.1995.tb02372.x

Lorenzo, P., Rodríguez-Echeverría, S., González, L., \& Freitas, H. (2010). Effect of invasive Acacia dealbata Link on soil microorganisms as determined by PCR-DGGE. Applied Soil Ecology, 44, 245-
251. http://dx.doi.org/10.1016/j.apsoil.2010.01.001

Lorquin, J., Lortet, G., Ferro, M., Mear, N., Prome, J. C., \& Boivin, C. (1997). Sinorhizobium teranga bv. acaciae ORS1073 and Rhizobium sp. strain ORS1001, two distantly related Acacia-nodulating strains, produce similar Nod factors that are O carbamoylated, N methylated, and mainly sulfated. Journal of Bacteriology, 179, 3079-3083.

Mendes, I. C., \& Bottomley, P. J. (1998). Distribution of a population of Rhizobium leguminosarum bv. trifolii among different size classes of soil aggregates. Applied and Environmental Microbiology, 64, 970-975.

Mohamed, S. H., Smouni, A., Neyra, M., Kharchaf, D., \& Filali-Maltouf, A. (2000). Phenotypic characteristics of root-nodulating bacteria isolated from Acacia spp. Grown in Libya. Plant Soil, 224, 171-183. http://dx.doi.org/10.1023/A:1004838218642

Moreira, F. M. S., da Silva, M. F., \& de Faria, S. M. (1992). Occurrence of nodulation in legume species in the Amazon region of Brasil. New Phytologist, 121, 563-570. http://dx.doi.org/10.1111/j.1469-8137.1992.tb01126.x

Muller, D., \& Okoro, C. E. (2004). Production and marketing of gumarabic (p. 81). NGARA Publication, Series 2, FAO \& ITC, Nairobi/Roma/Geneva, Kenya \& Italy \& Switzerland.

Nick, G., de Lajudie, P., Eardly, B. D., Suomalainen, S., Paulin, L., Zhang, X. et al. (1999). Sinorhizobium arboris sp. nov. and Sinorhizobium kostiense sp. nov., isolated from leguminous trees in Sudan and Kenya. International Journal of Systematic Bacteriology, 4, 1359-1368. http://dx.doi.org/10.1099/00207713-49-4-1359

Njiti, C. F., \& Galiana, A. (1996). Symbiotic properties and rhizobium requirements for effective nodulation of five tropical dry zone Acacias. Agroforestry Systems, 43, 265-275. http://dx.doi.org/10.1007/BF00046927

Normand, P., Cournoyer, B., Simonet, P., \& Nazaret, S. (1992). Analysis of a ribosomal RNA operon in the actinomycete Frankia. Gene, 111, 119-124. http://dx.doi.org/10.1016/0378-1119(92)90612-S

Pons, T. L., Perreijn, K., van Kessel, C., \& Werger, M. J. (2007). Symbiotic nitrogen fixation in a tropical rainforest: $15 \mathrm{~N}$ natural abundance measurements supported by experimental isotopic enrichment. New Phytologist, 173, 154-167. http://dx.doi.org/10.1111/j.1469-8137.2006.01895.x

Postma, J. G., Jager, D., Jacobsen, E., \& Feenstra, W. J. (1990). Studies on a non-fixing mutant of pea (Pisum sativum L.). Phenotypic description and bacteroid activity. Plant Science, 68, 151-161. http://dx.doi.org/10.1016/0168-9452(90)90220-I

Rodríguez-Echeverría, S. (2010). Rhizobial hitchhikers from Down Under: Invasional meltdown in a plant-bacteria mutualism? Journal of Biogeography, 37, 1611-1622.

Roggy, J. C., Prevost, M. F., Garbaye, J., \& Domenach, A. M. (1999). Nitrogen cycling in the tropical rain forest of French Guiana: Comparison of two sites with contrasting soil types using 15N. Journal of Tropical Ecology, 15, 1-22. http://dx.doi.org/10.1017/S0266467499000644

Sarr, A., Diop, B., Peltier, R., Neyra, M., \& Lesueur, D. (2005b). Effets of rhizobial inoculation methods and host plant provenances on nodulation and growth of Acacia senegal and Acacia nilotica. New Forest, 29, 75-87. http://dx.doi.org/10.1007/s11056-004-5232-z

Sarr, A., Neyra, M., Houeibib, M. A., Ndoye, I., Oihabi, A., \& Lesueur, D. (2005a). Rhizobial populations in soils from natural Acacia senegal and Acacia nilotica forests in Mauritania and the Senegal river valley. Microbial Ecology, 50, 152-162. http://dx.doi.org/10.1007/s00248-004-0077-8

Sylla, S. N., Samba, R. T., Neyra, M., Ndoye, I., Giraud, E., Willems, A. et al. (2002). Phenotypic and genotypic diversity of rhizobia nodulating Pterocarpus erinaceus and P. lucens in Senegal. Systematic and Applied Microbiology, 25, 572-583. http://dx.doi.org/10.1078/07232020260517715

Tamura, K., Peterson, D., Peterson, N., Stecher, G., Nei, M., \& Kumar, S. (2011). MEGA5: Molecular evolutionary genetics analysis using maximum likelihood, evolutionary distance, and maximum parsimony methods. Molecular Biology and Evolution, 28, 2731-2739. http://dx.doi.org/10.1093/molbev/msr121

Velazquez, E., Igual, J. M., Willems, A., Fernandez, M. P., Munoz, E., Mateos, P. F. et al. (2001). Mesorhizobium chacoense sp. nov., a 


\section{N. BAKHOUM ET AL.}

novel species that nodulates Prosopis alba in the Chaco Arido region (Argentina). International Journal of Systematic and Evolutionary Microbiology, 51, 1011-1021.

http://dx.doi.org/10.1099/00207713-51-3-1011

Willems, A., Coopman, R., \& Gillis, M. (2001). Comparison of sequence analysis of 16S-23S rDNA spacer regions, AFLP analysis and DNA-DNA hybridizations in Bradyrhizobium. International Journal of Systematic and Evolutionary Microbiology, 51, 623-632.

Xavier, G. R., Martins, L. M. V., Neves, M. C. P., \& Rumjanek, N. G.
(1998). Edaphic factors as determinants for the distribution of intrinsic antibiotic resistance in a cowpea rhizobia population. Biology and Fertility of Soils, 27, 386-392.

http://dx.doi.org/10.1007/s003740050448

Zhang, X., Harper, R., Karsisto, M., \& Lindström, K. (1991). Diversity of Rhizobium bacteria isolated from the root nodules of leguminous trees. International Journal of Systematic Bacteriology, 41, 104-113. http://dx.doi.org/10.1099/00207713-41-1-104 